OPEN ACCESS

Edited by:

Tony D. James,

University of Bath, United Kingdom

Reviewed by:

Xinhua Cao,

Xinyang Normal University, China

Peter Cragg,

University of Brighton,

United Kingdom

*Correspondence:

Jie Han

hanjie@nankai.edu.cn

Specialty section:

This article was submitted to

Supramolecular Chemistry,

a section of the journal

Frontiers in Chemistry

Received: 29 August 2021

Accepted: 18 October 2021

Published: 12 November 2021

Citation:

Sun C, Du S, Zhang T and Han J (2021)

A Novel Calix[4]Crown-Based 1,3,4-

Oxadiazole as a Fluorescent

Chemosensor for Copper(II)

Ion Detection.

Front. Chem. 9:766442.

doi: $10.3389 /$ fchem.2021.766442

\section{A Novel Calix[4]Crown-Based $1,3,4-$ Oxadiazole as a Fluorescent Chemosensor for Copper(II) Ion Detection}

\author{
Chun Sun, Siyi Du, Tianze Zhang and Jie Han* \\ Key Laboratory of Advanced Energy Materials Chemistry (Ministry of Energy), College of Chemistry, Nankai University, Tianjin, \\ China
}

The synthesis and characterization of a novel florescent chemosensor 1 with two different types of cationic binding sites have been reported in this work, which is a calix[4]crown derivative in 1,3-alternate conformation bearing two 2-phenyl-5-(4-dimethylaminopyenyl)1,3,4-oxadiazole units. The recognition behaviors of $\mathbf{1}$ in dichloromethane/acetonitrile solution to alkali metal ions $\left(\mathrm{Na}^{+}\right.$and $\left.\mathrm{K}^{+}\right)$, alkaline earth metal ions $\left(\mathrm{Mg}^{2+}\right.$ and $\left.\mathrm{Ca}^{2+}\right)$, and transition metal ions $\left(\mathrm{Co}^{2+}, \mathrm{Ni}^{2+}, \mathrm{Zn}^{2+}, \mathrm{Cd}^{2+}, \mathrm{Cu}^{2+}, \mathrm{Mn}^{2+}\right.$, and $\left.\mathrm{Ag}^{+}\right)$have been investigated by UV-Vis and fluorescence spectra. The fluorescence of $\mathbf{1}$ might be quenched selectively by $\mathrm{Cu}^{2+}$ due to the photo-induced electron transfer mechanism, and the quenched emission from 1 could be partly revived by the addition of $\mathrm{Ca}^{2+}$ or $\mathrm{Mg}^{2+}$; thus, the receptor 1 might be worked as an on-off switchable fluorescent chemosensor triggered by metal ion exchange. Keywords: calix[4]crown, 1,3-alternate conformation, 1,3,4-oxadiazole, copper (II) detection, fluorescent
chemosensor

\section{INTRODUCTION}

As the third most abundant transition metal ion after zinc and iron in the human body, copper is required by many living organisms for normal physiological processes (Turski and Thiele, 2009; Cotruvo Jr et al., 2015). Maintaining optimal concentration of $\mathrm{Cu}^{2+}$ ion for living cells is an essential factor to keep the normal functioning of enzymes and intracellular metabolic balance. Thus, the development of new fluorescent chemosensors for $\mathrm{Cu}^{2+}$ ion has drawn continuous interest during the past decades. The main progress in this area has been well reviewed (Cao et al., 2019; Sivaraman et al., 2018; Udhayakumari et al., 2017; Liu et al., 2017), and many fluorescent chemosensors for $\mathrm{Cu}^{2+}$ ion based on various fluorophores such as coumarin (Zhang et al., 2019), Bodipy (Ömeroğlu et al., 2021), rhodamine (Fernandes and Raimundo, 2021), Schiff base (Singh et al., 2020), pyrene (Kowser et al., 2021), and 1,3,4-oxadiazole (Wang, et al., 2018) have been reported by different research groups. Among these fluorescent chemosensors, the 1,3,4-oxadiazoles have drawn special interest due to their electron-deficient nature, high photoluminescence quantum yield, and excellent chemical stability, and have found practical applications in the fields of organic light-emitting diodes (Meng et al., 2020) and liquid crystals (Han et al., 2013; Han et al., 2015; Han et al., 2018). In addition, the nitrogen and oxygen atoms of the 1,3,4-oxadiazole unit can provide potential coordination sites with metal ions, which makes it usable as a signaling component in fluorescent chemosensors.

Calixarenes, as one kind of the most important super-molecules, have been widely used in design of fluorescent chemosensors for ions and neutral molecules due to their outstanding 


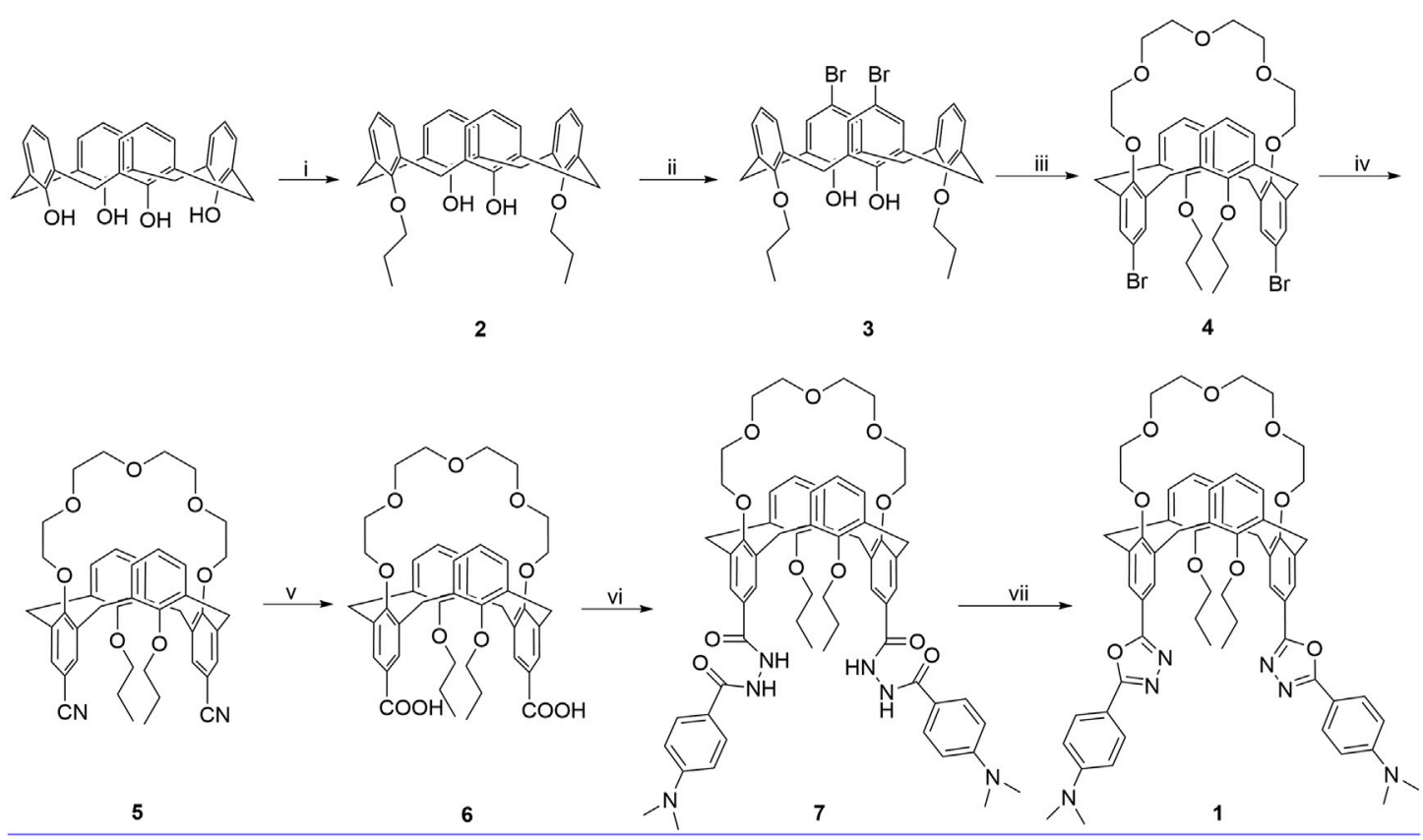

SCHEME 1 | Synthetic route for 1, reagents, and conditions: (i) 1-iodopropane, $\mathrm{K}_{2} \mathrm{CO}_{3}, \mathrm{CH}_{3} \mathrm{CN}$, reflux, $24 \mathrm{~h}$; (ii) $\mathrm{Br}_{2}$, $0^{\circ} \mathrm{C}, 3 \mathrm{~h}$; (iii) tetraethylene glycol ditosylate, $\mathrm{Cs}_{2} \mathrm{CO}_{3}, \mathrm{CH}_{3} \mathrm{CN}$, reflux, $72 \mathrm{~h}$; (iv) (1) $\mathrm{CuCN}, \mathrm{NMP}, 180^{\circ} \mathrm{C}, 5 \mathrm{~h}$; (2) $\mathrm{FeCl}_{3}, 2 \mathrm{M} \mathrm{HCl}, 100^{\circ} \mathrm{C}, 1 \mathrm{~h}$; (v) $\mathrm{KOH}$, ethanol, reflux, 24 h; (vi) (1) SOCl , toluene, reflux, 5 h; (2) $4-$ (dimethylamino)benzohydrazide, pyridine, r. t., 12 h; (vii) $\mathrm{POCl}_{3}$, reflux, 12 h.

features such as preorganized binding sites, easy derivatization, and flexible three-dimensional structures (Kim et al., 2012; An et al., 2019; Miranda et al., 2019; Noruzi et al., 2019; Chen et al., 2020). Many calixarene-based fluorescent chemosensors for transition metal ions have been reported in recent years (Ma et al., 2015). However, the fluorescent switchable chemosensors triggered by different ions are quite few (Chung et al., 2007), which remains a challenge in the field of supramolecular chemistry. Herein, as part of our continuous research in the design and synthesis of new fluorescent chemosensors (Liu et al., 2021; Xie et al., 2016; Han et al., 2012), we utilize the 1,3-alternate calix[4]crown scaffold to construct an on-off switchable fluorescent chemosensor $\mathbf{1}$ in this work. The synthetic route for $\mathbf{1}$ is shown in Scheme 1. There are quite a number of chemosensors based on various macrocycles for copper detection reported in literatures (Lvova, et al., 2018; Doumani, et al., Kamei, et al., 2021), in which the macrocyles often only worked as receptors for $\mathrm{Cu}^{2+}$ ions. In contrast, the chemosensor $\mathbf{1}$ in this work is special in that it has two kinds of macrocycles: one is from the 1,3-alternate calixarene, which provides a three-dimensional scaffold with two appending 1,3,4oxadiazole units as both signaling component and fluorophore; the other is from the calix[4]crown, which can bind the $\mathrm{Mg}^{2+}$ or $\mathrm{Ca}^{2+}$ ions and has an allosteric effect on the 1,3,4-oxadiazole units on opposite rings. The selective binding of 1,3,4oxadiazole with $\mathrm{Cu}^{2+}$ ions results in the fluorescence quenching, while the binding of calix[4]crown with $\mathrm{Mg}^{2+}$ or $\mathrm{Ca}^{2+}$ ions can partly revive the fluorescence consequently. Thus, the compound 1 might work as a new type of switchable off-on fluorescent chemosensor.

\section{MATERIALS AND METHODS}

25,27-Dihydroxy-26,28-dipropoxycalix[4]arene $\mathbf{2}$ and 5,17dibromo-25,27-dihydroxy-26,28-dipropoxycalix[4] arene 3 were synthesized according to the literature procedures (Hobzova, 2010). Dichloromethane and acetonitrile used for photophysical studies were of spectrometric grade. All the other chemicals and solvents were of analytical grade and used as received from commercial sources. The solutions of metal ions were all prepared from their perchlorate salts. Column chromatography was performed on silica gel (200-300 mesh).

Solution ${ }^{1} \mathrm{H}$ NMR (Proton Nuclear Magnetic Resonance) and ${ }^{13}$ C NMR (Carbon-13 Nuclear Magnetic Resonance) spectra were recorded on a Bruker AV400 spectrometer and the chemical shifts are quoted in parts per million ( $\mathrm{ppm}$ ) relative to tetramethylsilane (TMS) as an internal standard. ESI-HRMS (Electrospray Ionization-High Resolution Mass Spectrometry) data were obtained with a FTICR-MS mass spectrometer. Melting points were determined with an X-4 melting point apparatus, and the thermometer was uncorrected. Data for single $\mathrm{x}$-ray structure were collected on a SMART1000 CCD-X diffractometer with graphite-monochromatized MoKa x-ray radiation $(\lambda=0.71073 \AA)$ and Saturn CCD area detector. The $\mathrm{x}$-ray crystal structure of 4 was solved by direct method and expanded using Fourier synthesis technique. No absorption correction was done. The non-hydrogen atoms were refined anisotropically. Hydrogen atoms were refined using riding model. Structural refinement based on full-matrix least-squares refinement on $|\mathrm{F}|^{2}$ was performed by using Crystal Structure or SHELXL97 suite program (Sheldrick, 1997). 


\section{Synthesis of 4}

A mixture of $3(9.23 \mathrm{~g}, 13.9 \mathrm{mmol})$ and $\mathrm{Cs}_{2} \mathrm{CO}_{3}(11.30 \mathrm{~g}$, $34.7 \mathrm{mmol})$ in $\mathrm{MeCN}(700 \mathrm{ml})$ under nitrogen was stirred at reflux for $30 \mathrm{~min}$ and then a solution of the tetraethylene glycol ditosylate $(7.85 \mathrm{~g}, 15.6 \mathrm{mmol})$ in $\mathrm{MeCN}(40 \mathrm{ml})$ was added during an hour. The mixture was refluxed for $72 \mathrm{~h}$ and allowed to cool to room temperature. After evaporation of the solvent in vacuo, the residue was taken up in $\mathrm{CH}_{2} \mathrm{Cl}_{2}$ $(30 \mathrm{ml} \times 3)$ and the resultant solution was washed with $1 \mathrm{~mol} / \mathrm{L} \mathrm{HCl}(30 \mathrm{ml})$ and brine $(30 \mathrm{ml} \times 2)$. The organic layer was dried over $\mathrm{MgSO}_{4}$ and evaporated in vacuo. Recrystallization of the residue from $\mathrm{CH}_{2} \mathrm{Cl}_{2} / \mathrm{MeOH}$ gave 4 a pale-yellow solid. Yield, 75\%. Mp: $230-232{ }^{\circ} \mathrm{C} .{ }^{1} \mathrm{H}$ NMR $\left(400 \mathrm{MHz}, \mathrm{CDCl}_{3}\right) \delta 7.17(\mathrm{~s}, 4 \mathrm{H}), 7.08(\mathrm{~d}, \mathrm{~J}=8.0 \mathrm{~Hz}, 4 \mathrm{H})$, $6.87(\mathrm{t}, \mathrm{J}=8.0 \mathrm{~Hz}, 2 \mathrm{H}), 3.78(\mathrm{~d}, \mathrm{~J}=4.0 \mathrm{~Hz}, 8 \mathrm{H}), 3.54(\mathrm{~s}, 8 \mathrm{H}), 3.45$ $(\mathrm{t}, \mathrm{J}=8.0 \mathrm{~Hz}, 4 \mathrm{H}), 3.25-3.20(\mathrm{~m}, 4 \mathrm{H}), 3.15(\mathrm{~m}, 4 \mathrm{H}), 1.31(\mathrm{~m}$, $4 \mathrm{H}), 0.78(\mathrm{t}, \mathrm{J}=7.5 \mathrm{~Hz}, 6 \mathrm{H}) .{ }^{13} \mathrm{C} \mathrm{NMR}\left(101 \mathrm{MHz}, \mathrm{CDCl}_{3}\right) \delta$ $156.97,155.14,136.29,133.81,132.17,129.70,122.77,115.15$, $72.59,72.09,70.50,70.13,69.03,37.89,22.53,10.23$. HRMSMALDI calculated for $\mathrm{C}_{42} \mathrm{H}_{48} \mathrm{Br}_{2} \mathrm{O}_{7}[\mathrm{M}+\mathrm{Na}]{ }^{+} 847.1639$, found 847.1652 .

\section{Synthesis of 5}

Under nitrogen, a mixture of $4(10.17 \mathrm{~g}, 12.3 \mathrm{mmol})$ and cuprous cyanide $(7.68 \mathrm{~g}, 86.4 \mathrm{mmol})$ in $20 \mathrm{ml}$ of 1 -methyl2 -pyrrolidinone was stirred at $180^{\circ} \mathrm{C}$ for $4 \mathrm{~h}$. Then, the reaction mixture was cooled slowly to $100^{\circ} \mathrm{C}$, and a solution of $23.23 \mathrm{~g}(86.4 \mathrm{mmol})$ of $\mathrm{FeCl}_{3} \cdot 6 \mathrm{H}_{2} \mathrm{O}$ in $5 \mathrm{ml}$ of concentrated hydrochloride and $25 \mathrm{ml}$ of water was added to the reaction mixture. The reaction mixture was further stirred at $100^{\circ} \mathrm{C}$ for $1 \mathrm{~h}$ and cooled to room temperature. The solid was filtered off and recrystallized from chloroform/hexane yielding $5.5 \mathrm{~g}$ of compound 5 as yellow solid. Yield $62 \%$. ${ }^{1} \mathrm{H}$ NMR $(400 \mathrm{MHz}$, $\left.\mathrm{CDCl}_{3}\right) \delta 7.36(\mathrm{~s}, 4 \mathrm{H}), 7.10(\mathrm{~d}, \mathrm{~J}=7.4 \mathrm{~Hz}, 4 \mathrm{H}), 6.90(\mathrm{~s}, 2 \mathrm{H})$, $3.82(\mathrm{~d}, \mathrm{~J}=5.5 \mathrm{~Hz}, 8 \mathrm{H}), 3.55(\mathrm{~s}, 8 \mathrm{H}), 3.46(\mathrm{t}, \mathrm{J}=7.4 \mathrm{~Hz}, 4 \mathrm{H})$, $3.30(\mathrm{t}, \mathrm{J}=6.1 \mathrm{~Hz}, 4 \mathrm{H}), 3.17(\mathrm{t}, \mathrm{J}=6.1 \mathrm{~Hz}, 4 \mathrm{H}), 1.24(\mathrm{~m}, 4 \mathrm{H})$, $0.74(\mathrm{t}, \mathrm{J}=7.5 \mathrm{~Hz}, 6 \mathrm{H}) .{ }^{13} \mathrm{C} \mathrm{NMR}\left(101 \mathrm{MHz}, \mathrm{CDCl}_{3}\right) \delta 159.98$, $156.80,135.72,133.54,133.05,129.94,123.05,119.17,106.08$, 77.36, 72.52, 72.17, 70.56, 69.85, 69.13, 37.75, 22.81, 10.05; HRMS: calcd for $\mathrm{C}_{44} \mathrm{H}_{48} \mathrm{~N}_{2} \mathrm{O}_{7}\left[\mathrm{M}+\mathrm{NH}_{4}\right]^{+} 734.3800$, found 734.3796.

\section{Synthesis of 6}

A solution of $5.18 \mathrm{~g}(9.2 \mathrm{mmol})$ of $\mathrm{KOH}$ in $100 \mathrm{ml}$ of water was added to the suspension of $1.32 \mathrm{~g}(1.80 \mathrm{mmol})$ of $\mathbf{5}$ in $20 \mathrm{ml}$ of ethanol. The reaction mixture was heated under reflux for $24 \mathrm{~h}$. After cooling, the aqueous solution hydrogen chloride (10\% w/w) was added dropwise until the solution became slightly acidic. The precipitate was filtered off, washed with water, and dried to yield a yellow solid product 6 (1.33 g, 96\%). Mp: $296-298^{\circ} \mathrm{C}$. ${ }^{1} \mathrm{H}$ NMR $\left(400 \mathrm{MHz}, \mathrm{CDCl}_{3}\right) \delta 12.52(\mathrm{~s}, 2 \mathrm{H}), 7.81-7.77(\mathrm{~m}, 8 \mathrm{H}), 6.98-6.94$ $(\mathrm{m}, 2 \mathrm{H}), 3.93-3.80(\mathrm{~m}, 12 \mathrm{H}), 3.62(\mathrm{~s}, 16 \mathrm{H}), 1.42-1.31(\mathrm{~m}, 4 \mathrm{H})$, $0.69(\mathrm{t}, \mathrm{J}=7.5 \mathrm{~Hz}, 6 \mathrm{H}) .{ }^{13} \mathrm{C}$ NMR $\left(101 \mathrm{MHz}, \mathrm{DMSO}-d_{6}\right) \delta 167.03$, $158.48,156.72,135.62,133.71,132.13,130.41,125.24,122.05$, 71.17, 70.07, 69.72, 40.15, 39.94, 39.73, 39.52, 39.31, 39.10, 38.89, 35.98, 21.74, 9.52. HRMS: calcd for $\mathrm{C}_{44} \mathrm{H}_{50} \mathrm{O}_{11}[\mathrm{M}-\mathrm{H}]^{+} 753.3280$, found 753.3285 .

\section{Synthesis of 1}

To a round-bottomed flask was added $6(80 \mathrm{mg}, 0.1 \mathrm{mmol}), 10 \mathrm{ml}$ of toluene, and $1 \mathrm{ml}$ of thionyl chloride, and the mixture was refluxed for $5 \mathrm{~h}$. After cooling, the solvent and the excess of thionyl chloride were removed at reduced pressure to give the benzoyl chloride, which was added to a solution of 4(dimethylamino)benzohydrazide $(39 \mathrm{mg}, 0.22 \mathrm{mmol}$ ) in $10 \mathrm{ml}$ of dichloromethane and $0.1 \mathrm{ml}$ of pyridine. The reaction mixture was stirred for $12 \mathrm{~h}$ at ambient temperature and filtered. The precipitate was washed with ethanol to give the bishydrazide 7 as white solid, which was used to the next step reaction without further purification. The intermediate compound 7 was added to $\mathrm{POCl}_{3}(5 \mathrm{ml})$, and the resultant solution was refluxed overnight under a nitrogen atmosphere. After the reaction mixture cooled to room temperature, it was poured into ice water and extracted with dichloromethane $(3 \times$ $10 \mathrm{ml})$. The combined organic layer was washed with water and brine, respectively. Then, the solvent was removed under reduced pressure, and the crude solid was purified by silica gel column chromatography using petroleum ether/ethyl acetate (1:1) as eluent affording the product $\mathbf{1}$ as white solids. Yield, 35\%. Mp: 281-283 ${ }^{\circ}$. ${ }^{1} \mathrm{H}$ NMR $\left(400 \mathrm{MHz}, \mathrm{CDCl}_{3}\right) \delta 7.91(\mathrm{~d}, \mathrm{~J}=8.0 \mathrm{~Hz}$, $4 \mathrm{H}), 7.81(\mathrm{~s}, 4 \mathrm{H}), 7.15(\mathrm{~d}, \mathrm{~J}=8.0 \mathrm{~Hz}, 4 \mathrm{H}), 6.93(\mathrm{~s}, 2 \mathrm{H}), 6.72(\mathrm{~d}, \mathrm{~J}=$ $8.0 \mathrm{~Hz}, 4 \mathrm{H}), 3.93(\mathrm{~m}, 8 \mathrm{H}), 3.59-3.53(\mathrm{~m}, 12 \mathrm{H}), 3.31(\mathrm{~d}, \mathrm{~J}=5.2 \mathrm{~Hz}$, $4 \mathrm{H}), 3.26(\mathrm{~d}, \mathrm{~J}=5.2 \mathrm{~Hz}, 4 \mathrm{H}), 3.05(\mathrm{~m}, 12 \mathrm{H}), 1.25-1.19(\mathrm{~m}, 4 \mathrm{H})$, $0.60(\mathrm{t}, \mathrm{J}=7.4 \mathrm{~Hz}, 6 \mathrm{H}) .{ }^{13} \mathrm{C} \mathrm{NMR}\left(101 \mathrm{MHz}, \mathrm{CDCl}_{3}\right) \delta 164.80$, $163.55,158.76,157.10,152.20,135.07,133.83,129.79,128.32$, $128.13,122.75,121.14,118.35,111.59,111.27,72.43,72.24,70.42$, $70.14,69.22,40.11,38.05,22.43,9.95$. HRMS-ESI calculated for $\mathrm{C}_{62} \mathrm{H}_{69} \mathrm{~N}_{6} \mathrm{O}_{9}[\mathrm{M}+\mathrm{H}]+1,041.5120$, found $1,041.5126$. (Supplementary Figure S5, ESI).

\section{General Procedures for the UV/Vis and Fluorescence Experiments}

UV-vis spectra were recorded on a Cary 3,010 spectrophotometer, and the resolution was set at $1 \mathrm{~nm}$. Steadystate emission spectra were recorded on a Varian Cary Eclipse spectrometer. For all measurements of fluorescence spectra, excitation was set at $334 \mathrm{~nm}$ for complexation, and the excitation and emission slit width was set to be $2.5 \mathrm{~nm}$. Fluorescence titration experiments were performed with $\mathrm{CH}_{2} \mathrm{Cl}_{2}$ solutions of compound $\mathbf{1}$ and varying concentrations of metal perchlorate in $\mathrm{CH}_{3} \mathrm{CN}$ solution. During all measurements, the temperature of the quartz sample cell and chamber was kept at $25^{\circ} \mathrm{C}$.

\section{RESULTS AND DISCUSSION}

\section{Synthesis and Structural Analysis}

As shown in Scheme 1, calix[4]arene $\mathbf{3}$ was reacted with tetraethylene glycol ditosylate in the presence of $\mathrm{Cs}_{2} \mathrm{CO}_{3}$ to successfully afford the calix[4]crown 3 in $75 \%$ yield. The substitution reaction of 4 with $\mathrm{CuCN}$ gave 5 in $62 \%$ yield, which was refluxed with $\mathrm{KOH}$ in ethanol and treated with hydrochloric acid solution, readily providing the carboxylic 


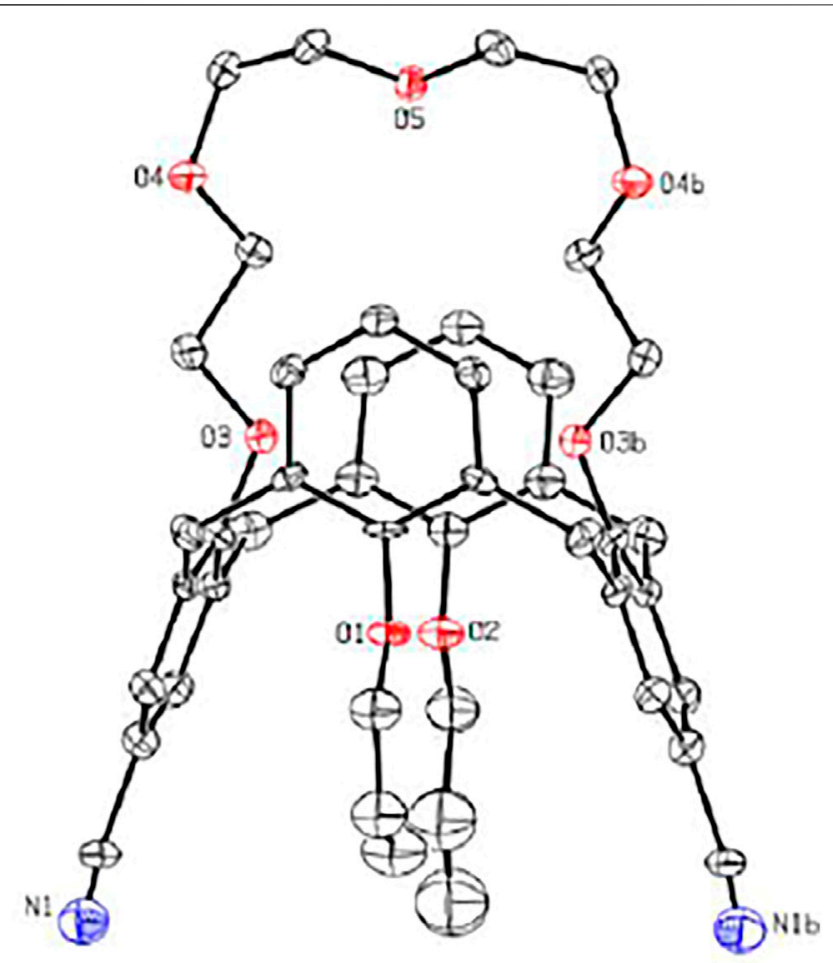

FIGURE 1 | X-ray molecular structure of $\mathbf{5}$.

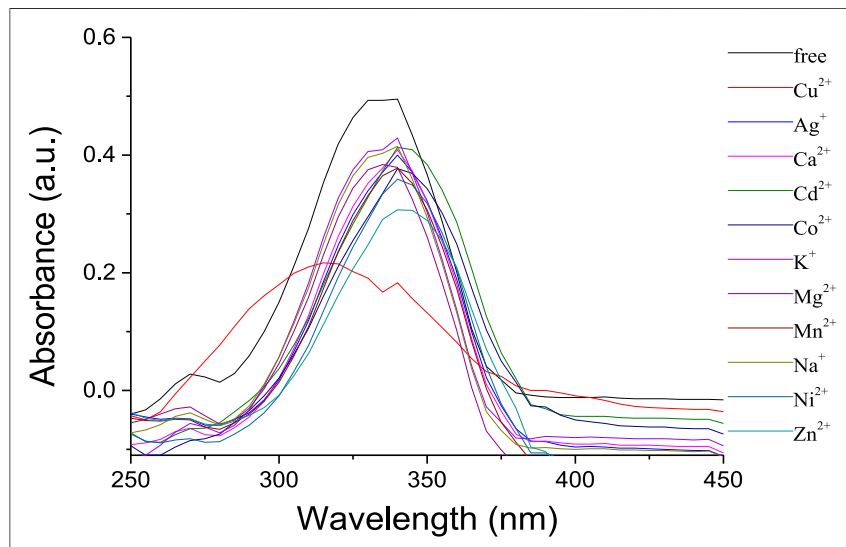

FIGURE 2 | UV-vis spectra of $\mathbf{1}\left(1 \times 10^{-6} \mathrm{~mol} / \mathrm{L}\right)$ upon addition of metal ions (10 equiv) in $\mathrm{CH}_{2} \mathrm{Cl}_{2} / \mathrm{CH}_{3} \mathrm{CN}(1,000: 1, \mathrm{v} / \mathrm{v})$.

acid $\mathbf{6}$ in good yield. Then, the carboxylic acid $\mathbf{6}$ was reacted with thionyl chloride, and treated with benzyol hydrazine or $4-\mathrm{N}, \mathrm{N}^{\prime}$ dimethylaminobenzyol hydrazine to generate the intermediate bishydrazide 7, which was used in the next step without purification and refluxed with phosphorus oxychloride to afford the target products 1. Except for the calix[4]arene 3, all of the intermediate calix[4]crowns 3-6 and the chemosensor $\mathbf{1}$ are in 1,3-alternate conformation, which were well established by ${ }^{1} \mathrm{H}$ NMR and ${ }^{13} \mathrm{C}$ NMR data (Supplementary Figures S1-S4,

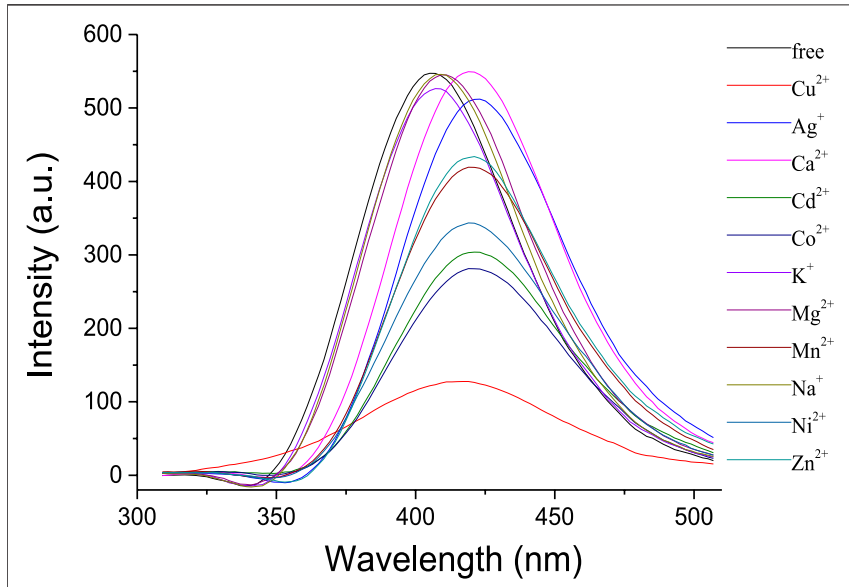

FIGURE 3 | Fluorescence spectra $\left(\lambda_{\text {exc }}=334 \mathrm{~nm}\right.$, Slit $\left.=2.5\right)$ of $\mathbf{1}(1 \times$ $10^{-6} \mathrm{~mol} / \mathrm{L}$ ) upon addition of metal ions (10 equiv) in $\mathrm{CH}_{2} \mathrm{Cl}_{2} / \mathrm{CH}_{3} \mathrm{CN}(1,000: 1$, $\mathrm{v} / \mathrm{v})$

ESI). The 1,3-alternate conformation of $\mathbf{5}$ was further confirmed unambiguously by $\mathrm{x}$-ray single crystal diffraction as shown in Figure 1. The $\mathrm{x}$-ray crystallographic data are collected in Supplementary Table S1.

\section{UV-Vis Absorption and Fluorescence Spectra Analysis}

The selectivity of the receptor $\mathbf{1}$ toward different perchlorate salts, including $\mathrm{Na}^{+}, \mathrm{K}^{+}, \mathrm{Mg}^{2+}, \mathrm{Ca}^{2+}, \mathrm{Co}^{2+}, \mathrm{Ni}^{2+}, \mathrm{Zn}^{2+}, \mathrm{Cd}^{2+}, \mathrm{Mn}^{2+}, \mathrm{Ag}^{+}$, and $\mathrm{Cu}^{2+}$, was first investigated by UV-Vis spectroscopy. The UVVis absorption spectra for free $\mathbf{1}$ in $\mathrm{CH}_{2} \mathrm{Cl}_{2}$ solution showed an intense and structureless absorption band $\left(\varepsilon=4.94 \times 10^{5} \mathrm{~L} / \mathrm{mol} \cdot \mathrm{cm}\right)$ peaking at $340 \mathrm{~nm}$ (Figure 2), which might have resulted from the spin-allowed $\pi-\pi^{\star}$ transitions involving the phenyloxadiazole moiety (Han et al., 2006). The addition of $\mathrm{Cu}^{2+}$ ions in the solution of 1 resulted in a significant decrease in the absorbance with an appreciable hypochromic shift of $20 \mathrm{~nm}$. In contrast, only a slight decrease was observed upon addition of other metal ions mentioned above, which suggested that the selectivity of $\mathbf{1}$ toward $\mathrm{Cu}^{2+}$ is much higher than the other metal ions.

Ion recognition ability of $\mathbf{1}$ was further studied by the fluorescence spectra. As shown in Figure 3, the receptor 1 exhibited a strong emission with $\lambda_{\max }$ at $405 \mathrm{~nm}$ in solution of $\mathrm{CH}_{2} \mathrm{Cl}_{2}$. Upon addition of $\mathrm{Na}^{+}, \mathrm{K}^{+}$, and $\mathrm{Mg}^{2+}$, respectively, almost no changes were observed in the intensity and shape of the emission spectra of $\mathbf{1}$. It is noted that the addition of $\mathrm{Ca}^{2+}$ might slightly increase the intensity with a bathochromic shift of ca. $15 \mathrm{~nm}$, perhaps because the complexation between the $\mathrm{Ca}^{2+}$ and the crown ether moiety changed the space distance of the two phenyloxadiazole units and the fluorescence changed consequently. Apparently, the fluorescence response of $\mathbf{1}$ toward transition metal ions was found to be more pronounced, and the addition of $\mathrm{Co}^{2+}, \mathrm{Ni}^{2+}, \mathrm{Zn}^{2+}$, and $\mathrm{Ag}^{+}$ could quench the emission of $\mathbf{1}$ in a different extent, accompanied by a concomitant red shift of ca. $14-17 \mathrm{~nm}$. In contrast, the addition of $\mathrm{Cu}^{2+}$ significantly quenched the 


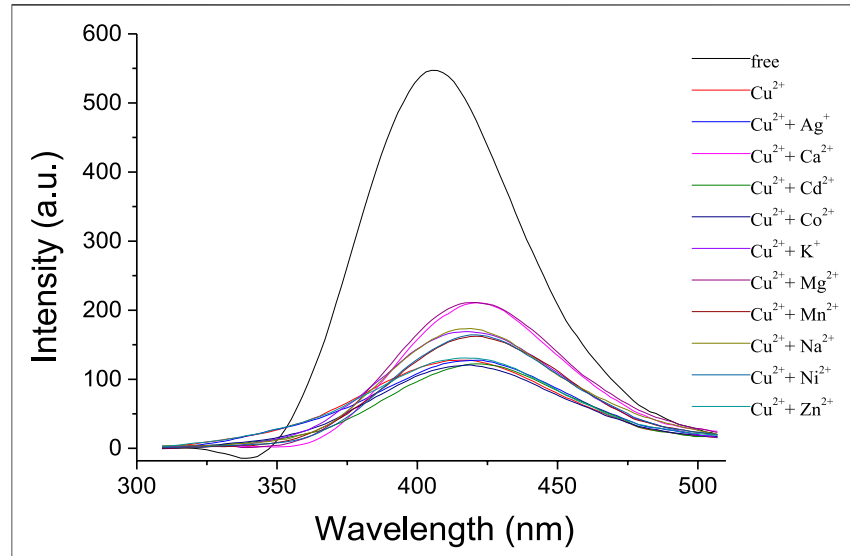

FIGURE 4 | Fluorescence spectra $\left(\lambda_{\text {exc }}=334 \mathrm{~nm}\right.$, Slit $\left.=2.5\right)$ of $\mathbf{1}(1 \times$ $\left.10^{-6} \mathrm{~mol} / \mathrm{L}\right)$ and $\mathrm{Cu}^{2+}(10$ equiv) upon addition of other metal ions (10 equiv) in $\mathrm{CH}_{2} \mathrm{Cl}_{2} / \mathrm{CH}_{3} \mathrm{CN}(1,000: 1$, v/v)

fluorescence of $\mathbf{1}$ under the same conditions as the aforementioned metal ions, suggesting that there is a strong interaction between 1,3,4-oxadiazole moieties of $\mathbf{1}$ and $\mathrm{Cu}^{2+}$ ion over the other metal ions.

The fluorescence emission properties of $\mathbf{1}$ in the presence of $\mathrm{Cu}^{2+}$ and a competitive metal ion were measured to investigate the selective recognition for $\mathrm{Cu}^{2+}$. As shown in Figure 4, no apparent changes were observed in fluorescence intensity when 10 equivalent amounts of transition metal ions $\left(\mathrm{Co}^{2+}, \mathrm{Ni}^{2+}, \mathrm{Zn}^{2+}, \mathrm{Cd}^{2+}, \mathrm{Mn}^{2+}\right.$, and $\left.\mathrm{Ag}^{+}\right)$were added to the solution of $\mathbf{1}$ and $\mathrm{Cu}^{2+}$ (10 equiv). This suggested that the recognition for $\mathrm{Cu}^{2+}$ was not interrupted by the competitive transition metal ions; thus, the receptor $\mathbf{1}$ might act as a selective fluorescent chemosensor for $\mathrm{Cu}^{2+}$. The addition of alkali metal ions $\left(\mathrm{Na}^{+}\right.$and $\left.\mathrm{K}^{+}\right)$to the solution of $\mathbf{1}$ and $\mathrm{Cu}^{2+}$ could increase the fluorescence intensity slightly, while the alkaline earth metal ions $\left(\mathrm{Mg}^{2+}\right.$ and $\left.\mathrm{Ca}^{2+}\right)$ could revive the emission significantly.

In order to elicit the binding property of the chemosensor 1 toward $\mathrm{Cu}^{2+}$ ion, fluorescence titration of $1\left(1.0 \times 10^{-5} \mathrm{~mol} / \mathrm{L}\right)$ with $\mathrm{Cu}^{2+}$ ion (0-2 equiv) was carried out (Supplementary Figure S6). According to the fluorescence titration curves of 1 with $\mathrm{Cu}^{2+}$ ion at room temperatures, the association constant $K_{a}$ was calculated as $1.6 \times 10^{-4} \mathrm{~L} \cdot \mathrm{mol}^{-1}(R=0.97526)$ for the $1-\mathrm{Cu}^{2+}$ complex by the Benesi-Hildebrand plot (Thordarson, 2011) (Figure 5). Moreover, the emission intensity of $\mathbf{1}$ is linearly proportional to the $\mathrm{Cu}^{2+}$ concentration in the range of $0-20 \mu \mathrm{M}$.

The fluorescence changes of $\mathbf{1}$ upon addition of $\mathrm{Cu}^{2+}$ and $\mathrm{Mg}^{2+}$ ions are displayed in Figure 6. The nitrogen atoms of the 1,3,4-oxadiazle units can bind with $\mathrm{Cu}^{2+}$ to form the complex $\mathbf{1} \cdot \mathrm{Cu}^{2+}$, and the paramagnetic nature of $\mathrm{Cu}^{2+}$ ion could strongly quench the fluorescence of the 1,3,4-oxadiazole units through the electron transfer mechanism, which is consistent to the results reported in literature (Han et al., 2012). In contrast, the polyether ring (crown-5 moiety) and the oxygens from the two propoxyl groups could provide coordination sites with the alkaline earth metal ions to form the complex $1 \cdot \mathrm{Mg}^{2+}$, which will change the molecular conformation as well as the space distance of the two 1,3,4-oxadiazole units. Consequently, the decomplexations between the 1,3,4-oxadiazoles and $\mathrm{Cu}^{2+}$ ions took place and resulted in the increase of the fluorescence. Thus, the receptor 1 might be acted as an on-off-on switchable fluorescent chemosensor triggered by the exchange of $\mathrm{Cu}^{2+}$ and $\mathrm{Mg}^{2+}$.

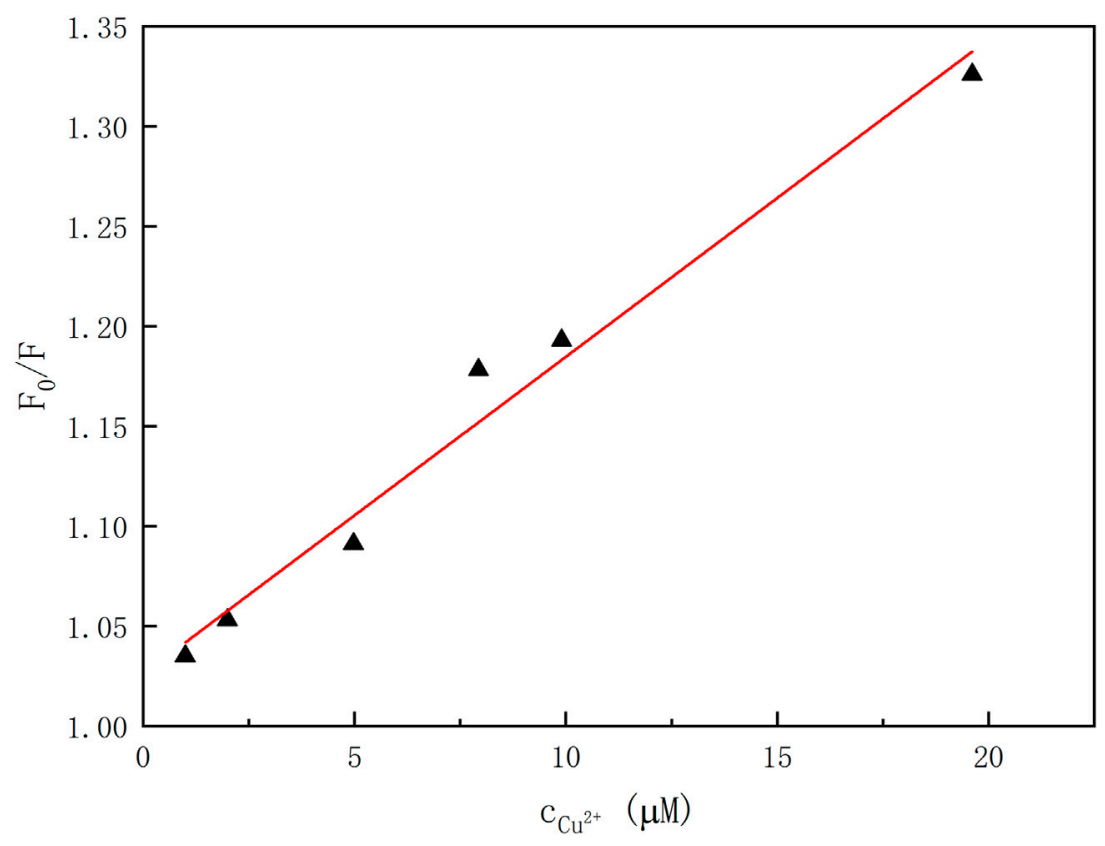

FIGURE 5 | Plot of emission intensity versus the concentrations of $\mathrm{Cu}^{2+}$ ion $\left(\lambda_{\mathrm{em}}=405 \mathrm{~nm}, \lambda_{\mathrm{ex}}=334 \mathrm{~nm}\right)$ 


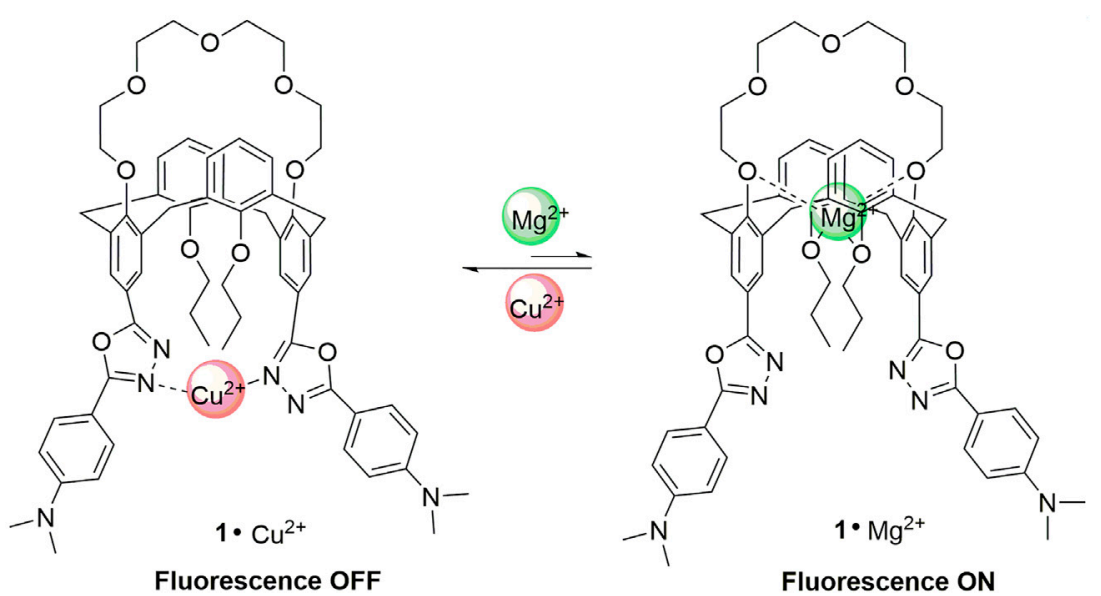

FIGURE $\mathbf{6}$ | The complexation of $\mathbf{1}$ with $\mathrm{Cu}^{2+}$ and $\mathrm{Mg}^{2+}$ ions.

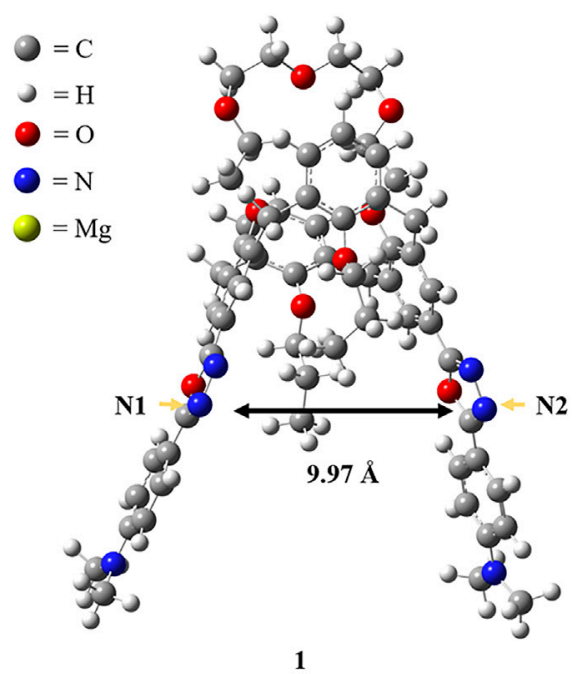

1

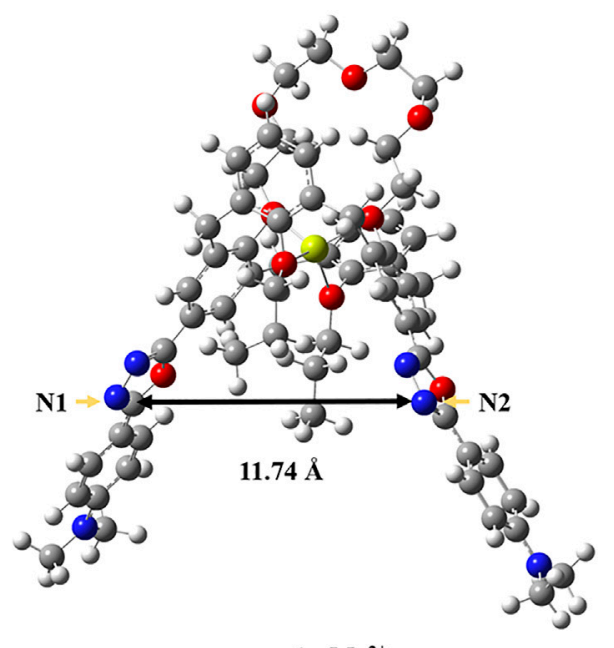

$\mathbf{1} \cdot \mathrm{Mg}^{2+}$

FIGURE $\mathbf{7}$ | Computational optimized molecular structures of $\mathbf{1}$ and $\mathbf{1} \cdot \mathbf{M g}^{\mathbf{2 +}}$

To gain a better understanding about the switchable fluorescence of the chemosensor 1, DFT calculations with the GAUSSIAN 09 series of programs (Frisch et al., 2013) were carried out to analyze the molecular structures of $\mathbf{1}$ and $\mathbf{1} \cdot \mathrm{Mg}^{2+}$, and DFT method B3-LYP with 6-31G(d) basis set was used for geometry optimizations (A. D. Becke, 1993). As shown in Figure 7, the distance between N1 and N2 in the free receptor 1 is $9.97 \AA$, while the corresponding distance is $11.74 \AA$ in the complex $\mathbf{1} \cdot \mathbf{M g}^{2+}$, indicating that the molecular conformation changed simultaneously due to the allosteric effect (Kumar et al., 2012; Ni et al., 2013). The conformational change as well as the increase in distance makes it difficult for the chemosensor 1 to coordinate with $\mathrm{Cu}^{2+}$ ion to form the stable complex, which reasonably explains the fact that the addition of
$\mathrm{Mg}^{2+}$ ions to the solution of $\mathbf{1}$ and $\mathrm{Cu}^{2+}$ can trigger the revival of fluorescence.

\section{CONCLUSION}

In summary, we have designed a new type of fluorescent chemosensor based on a 1,3-alternate calix[4]crown with two different cationic binding sites. The 1,3,4-oxadiazole units could bind selectively with $\mathrm{Cu}^{2+}$ to form the complexation and resulted in the fluorescence quenching of the chemosensor. The presence of various transition metal ions does not interfere with the quenching process, while the alkaline earth metal ions $\mathrm{Mg}^{2+}$ might be entrapped by the crown- 5 moiety and revive the fluorescence significantly due to the allosteric effect. As the 
chemosensor in this work is not soluble in water, it is difficult to investigate the $\mathrm{Cu}^{2+}$ ions' detection under physiological conditions. Devising a water-soluble chemosensor for $\mathrm{Cu}^{2+}$ ions is in progress in our lab.

\section{DATA AVAILABILITY STATEMENT}

The original contributions presented in the study are included in the article/Supplementary Material, further inquiries can be directed to the corresponding author.

\section{AUTHOR CONTRIBUTIONS}

JH designed the work and wrote the manuscript. CS synthesized and characterized the compounds. CS and SD carried out the

\section{REFERENCES}

An, L., Wang, C., Han, L., Liu, J., Huang, T., Zheng, Y., et al. (2019). Structural Design, Synthesis, and Preliminary Biological Evaluation of Novel Dihomooxacalix[4]arene-Based Anti-tumor Agent. Front. Chem. 7, 856. doi: $10.3389 /$ fchem. 2019.00856

Becke, A. D. (1993). Density-functional Thermochemistry. III. The Role of Exact Exchange. J. Chem. Phys. 98, 5648. doi:10.1063/1.464913

Cao, X., Li, Y., Gao, A., Yu, Y., Zhou, Q., and Chang, X. (2019). Multifunctional Fluorescent Naphthalimide Self-Assembly System for the Detection of $\mathrm{Cu}^{2+}$ and $\mathrm{K}^{+}$and Continuous Sensing of Organic Amines and Gaseous Acids. J. Mater. Chem. C 7, 10589-10597. doi:10.1039/c9tc03243f

Chang, K.-C., Su, I.-H., Senthilvelan, A., and Chung, W.-S. (2007). Triazolemodified Calix[4]crown as Novel Fluorescent On-Off Switchable Chemosensor. Org. Lett. 9, 3363-3366. doi:10.1021/ol071337+

Chen, Y.-J., Chen, M.-Y., Lee, K.-T., Shen, L.-C., Hung, H.-C., Niu, H.-C., et al. (2020). 1,3-Alternate Calix[4]arene Functionalized with Pyrazole and Triazole Ligands as a Highly Selective Fluorescent Sensor for $\mathrm{Hg}^{2+}$ and Ag+ Ions. Front. Chem. 6, 593261. doi:10.3389/fchem.2019.59326110.3389/ fchem.2020.593261

Cotruvo, Jr., J. A., Jr., Aron, A. T., Ramos-Torres, K. M., and Chang, C. J. (2015). Synthetic Fluorescent Probes for Studying Copper in Biological Systems. Chem. Soc. Rev. 44, 4400-4414. doi:10.1039/c4cs00346b

Doumani, N., Bou-Maroun, E., Maalouly, J., Tueni, M., Dubois, A., Bernhard, C., et al. (2019). A New pH-dependent Macrocyclic Rhodamine B-Based Fluorescent Probe for Copper Detection in white Wine. Sensors 19, 4514. doi:10.3390/s19204514

Fernandes, R. da. S., and Raimundo, I. M., Jr (2021). Development of a Reusable Fluorescent Nanosensor Based on Rhodamine B Immobilized in Stober Silica for Copper Ion Detection. Anal. Methods 13, 1970-1975. doi:10.1039/ dlay00168j

Frisch, M. J., Trucks, G. W., Schlegel, H. B., Scuseria, G. E., Robb, M. A., Cheeseman, J. R., et al. (2013). Gaussian 09, Revision D.01. Wallingford, CT: Gaussian, Inc.

Han, J. (2013). 1,3,4-Oxadiazole Based Liquid Crystals. J. Mater. Chem. C. 1, 7779-7797. doi:10.1039/c3tc31458h

Han, J., Chui, S. S. Y., and Che, C. M. (2006). Thermotropic Liquid Crystals Based on Extended 2,5-Disubstituted-1,3,4-Oxadiazoles: Structure-Property Relationships, Variable-Temperature Powder X-ray Diffraction, and SmallAngel X-ray Scattering Studies. Chem. Asian J. 1, 814-825. doi:10.1002/ asia. 200600252

Han, J., Wang, F.-L., Liu, Y.-X., Zhang, F.-Y., Meng, J.-B., and He, Z.-J. (2012). Calix[4]arene-based 1,3,4-oxadiazole: Novel Fluorescent Chemosensors for Specific Recognition of $\mathrm{Cu}^{2+}$. ChemPlusChem 77, 196-200. doi:10.1002/ cplu.201200004
UV-Vis absorption and fluorescence studies. TZ carried out the DFT calculations. JH revised and edited the manuscript. All authors contributed to discussion on the results for the manuscript.

\section{FUNDING}

This work was financially supported by the National Natural Science Foundation of China (No. 21272130) and the 111 Project (grant no. B12015).

\section{SUPPLEMENTARY MATERIAL}

The Supplementary Material for this article can be found online at: https:/www.frontiersin.org/articles/10.3389/fchem.2021.766442/ full\#supplementary-material

Han, J., Wang, Z.-Z., Wu, J., and Zhu, L.-R. (2015). A Room-Temperature Liquid Crystalline Polymer Based on Discotic 1,3,4-oxadiazole. RSC Adv. 5, 47579-47583. doi:10.1039/c5ra05983f

Han, J., Xi, Z., Wang, F., Bu, L., and Wang, Y. (2018). Synthesis, Liquid Crystalline and Photoluminscent Properties of 1,3,4-oxadiazole Derivatives: from Calamitic Monomers, H-Shaped Dimers to Calix[4]arene-Based Tetramers. Dyes Pigm. 154, 234-241. doi:10.1016/j.dyepig.2018.03.008

Hobzova, R., Sysel, P., and Duskova-Smrckova, M. (2010). Synthesis and Characterization of Calix[4]arene-Containing Polyimides. Polym. Int. 60, 405-413. doi:10.1002/pi.2962

Kamel, A. H., Amr, A. E.-G. E., Almehizia, A. A., Elsayed, E. A., and Moustafa, G. O. (2021). Low-cost Potentiometric Paper-Based Analytical Device Based on Newly Synthesized Macrocyclic Pyrido-Pentapeptide Derivatives as Novel Ionophores for point-of-care Copper(II) Determination. RSC Adv. 11, 27174-27182. doi:10.1039/d1ra04712d

Kim, H. J., Min Hee Lee, M. H., Mutihac, L., Vicens, J., and Kim, J. S. (2012). Host-guest Sensing by Calixarenes on the Surfaces. Chem. Soc. Rev. 41, 1173-1190. doi:10.1039/c1cs15169j

Kowser, Z., Rayhan, U., Akther, T., Redshaw, C., and Yamato, T. (2021). A Brief Review on Novel Pyrene Based Fluorometric and Colorimetric Chemosensors for the Detection of $\mathrm{Cu}^{2+}$. Mater. Chem. Front. 5, 2173-2200. doi:10.1039/ D0QM01008A

Kumar, M., Kumar, N., and Bhalla, V. (2012). Ratiometric Nanomolar Detection of $\mathrm{Cu}^{2+}$ Ions in Mixed Aqueous media: a $\mathrm{Cu}^{2+} / \mathrm{Li}^{+}$Ions Switchable Allosteric System Based on Thiacalix[4]crown. Dalton Trans. 41, 10189-10193. doi:10.1039/c2dt31081c

Liu, S., Wang, Y.-M., and Han, J. (2017). Fluorescent Chemosensors for Copper(II) Ion: Structure, Mechanism and Application. J. Photochem. Photobio. C. 32, 78-103. doi:10.1016/j.jphotochemrev.2017.06.002

Liu, S., Wu, Q., Zhang, T., Zhang, H., and Han, J. (2021). Supramolecular brush Polymers Prepared from 1,3,4-oxadiazole and Cyanobutoxy Functionalized Pillar[5]arene for Detecting $\mathrm{Cu}^{2+}$. Org. Biomol. Chem. 19, 1287-1291. doi:10.1039/d0ob02587a

Lvova, L., Caroleo, F., Garau, A., Lippolis, V., Giorgi, L., Fusi, V., et al. (2018). A Fluorescent Sensor Array Based on Heteroatomic Macrocyclic Fluorophores for the Detection of Polluting Species in Natural Water Samples. Front. Chem. 6, 258. doi: $10.3389 /$ fchem. 2018.00258

Ma, J., Song, M., Boussouar, I., Tian, D., and Li, H. (2015). Recent Progress of Calixarene-Based Fluorescent Chemosensors towards Mercury Ions. Supramole. Chem. 27, 444-452. doi:10.1080/10610278.2014.988627

Meng, X., Wang, P., Bai, R., and He, L. (2020). Blue-green-emitting Cationic Iridium Complexes with Oxadiazole-type Counter-anions and Their Use for Highly Efficient Solution-Processed Organic Light-Emitting Diodes. J. Mater. Chem. C 8, 6236-6244. doi:10.1039/d0tc01054e

Miranda, A. S., Serbetci, D., Marcos, P. M., Ascenso, J. R., Berberan-Santos, M. N., Hickey, N., et al. (2019). Ditopic Receptors Based on Dihomooxacalix[4]arenes 
Bearing Phenylurea Moieties with Electron-Withdrawing Groups for Anions and Organic Ion Pairs. Front. Chem. 7, 758. doi:10.3389/fchem.2019.00758

Ni, X.-L., Cong, H., Yoshizawa, A., Rahman, S., Tomiyasu, H., Rayhan, U., et al. (2013). Heteroditopic Thiacalix[4]arene Receptor Having Ester and Bipyridyl Moieties for Ions Binding with Positive/negative Allosteric Effect. J. Mol. Struc. 1046, 110-115. doi:10.1016/j.molstruc.2013.04.040

Noruzi, E. B., Kheirkhahi, M., Shaabani, B., Geremia, S., Hickey, N., Asaro, F., et al. (2019). Design of a Thiosemicarbazide-Functionalized Calix[4]arene Ligand and Related Transition Metal Complexes: Synthesis, Characterization, and Biological Studies. Front. Chem. 7, 663. doi:10.3389/ fchem.2019.00663

Ömeroğlu, İ., Tümay, S. O., Makhseed, S., Husain, A., and Durmuş, M. (2021). A Highly Sensitive "ON-OFF-ON" Dual Optical Sensor for the Detection of $\mathrm{Cu}$ (II) Ion and Triazole Pesticides Based on Novel BODIPY-Substituted Cavitand. Dalton Trans. 50, 6437-6443. doi:10.1039/d1dt00792k

Sheldrick, G. M. (1997). SHELXS-97 and SHELXL-97. Gottingen: University of Gottingen.

Singh, G., Shilpy, Singh, A., Dikshaand, Pawan. (2020). Synthesis of Organosilocane Allied N-Heteroaryl Schiff Base Chemosensor for the Detection of $\mathrm{Cu}^{2+}$ Metal Ions and Their Biological Applications. New J. Chem. 44, 13542-13552. doi:10.1039/d0nj01774d

Sivaraman, G., Iniy, M., Anand, T., Kotla, N. G., Sunnapu, O., Singaravadivel, S., et al. (2018). Chemically Diverse Small Molecule Fluorescent Chemosensors for Copper Ion. Coord. Chem. Rev. 357, 50-104. doi:10.1016/j.ccr.2017.11.020

Thordarson, P. (2011). Determining Association Constants from Titration Experiments in Supramolecular Chemistry. Chem. Soc. Rev. 40, 1305-1323. doi: $10.1039 / \mathrm{c} 0 \mathrm{cs} 00062 \mathrm{k}$

Turski, M. L., and Thiele, D. J. (2009). New Roles for Copper Metabolism in Cell Proliferation, Signaling, and Disease. J. Biol. Chem. 284, 717-721. doi:10.1074/ jbc.R800055200
Udhayakumari, D., Naha, S., and Velmathi, S. (2017). Colorimetric and Fluorescent Chemosensors for $\mathrm{Cu}^{2+}$. A Comprehensive Review from the Years 2013-15. Anal. Methods 9, 552-578. doi:10.1039/c6ay02416e

Wang, L., Gong, X., Bing, Q., and Wang, G. (2018). A New Oxadiazole-Based DualMode Chemosensor: Colorimetric Detection of $\mathrm{Co}^{2+}$ and Fluorometric Detection of $\mathrm{Cu}^{2+}$ with High Selectivity and Sensitivity. Microchem. J. 142, 279-287. doi:10.1016/j.microc.2018.07.008

Xie, D.-H., Wang, X.-J., Sun, C., and Han, J. (2016). Calix[4]arene Based 1,3,4oxadiazole as a Fluorescent Chemosensor for Copper(II) Ion Detection. Tetrahedron Lett. 57, 5834-5836. doi:10.1016/j.tetlet.2016.11.051

Zhang, Z., Liu, Y., and Wang, E. (2019). A Highly Selective "Turn-on" Fluorescent Probe for Detecting $\mathrm{Cu}^{2+}$ in Two Different Sensing Mechanisms. Dyes Pigm. 163, 533-537. doi:10.1016/j.dyepig.2018.12.039

Conflict of Interest: The authors declare that the research was conducted in the absence of any commercial or financial relationships that could be construed as a potential conflict of interest.

Publisher's Note: All claims expressed in this article are solely those of the authors and do not necessarily represent those of their affiliated organizations, or those of the publisher, the editors and the reviewers. Any product that may be evaluated in this article, or claim that may be made by its manufacturer, is not guaranteed or endorsed by the publisher.

Copyright (c) 2021 Sun, Du, Zhang and Han. This is an open-access article distributed under the terms of the Creative Commons Attribution License (CC $B Y$ ). The use, distribution or reproduction in other forums is permitted, provided the original author(s) and the copyright owner(s) are credited and that the original publication in this journal is cited, in accordance with accepted academic practice. No use, distribution or reproduction is permitted which does not comply with these terms. 